\title{
Advanced glycation end products induce proliferation, invasion and epithelial-mesenchymal transition of human SW480 colon cancer cells through the PI3K/AKT signaling pathway
}

\author{
HUASHENG LIANG \\ Institute of Endocrine and Metabolic Diseases, Beihai People's Hospital, Beihai, \\ Guangxi Zhuang Autonomous Region 536000, P.R. China \\ Received June 12, 2019; Accepted January 14, 2020
}

DOI: $10.3892 / \mathrm{ol} .2020 .11413$

\begin{abstract}
The aim of the present study was to determine the mechanism by which advanced glycation end products (AGEs) induce proliferation, invasion and epithelial-mesenchymal transition (EMT) of human colon cancer SW480 cells. SW480 cells were divided into groups as follows: i) Control; ii) cells treated with AGEs alone; and iii) cells treated with AGEs combined with LY294002. Proliferation, cell cycle progression, apoptosis, invasion and migration of SW480 cells were assessed using an MTT assay, flow cytometry, Transwell assays and a wound healing assay, respectively. The protein expression levels of PI3K, AKT and epithelial cadherin (E-cadherin) were examined by western blot analysis in SW480 cells treated with various concentrations of AGEs. Proliferation, invasion and migration were enhanced, cell cycle progression was increased and apoptosis was decreased in SW480 cells treated with AGEs compared with the control. The PI3K inhibitor, LY294002, reversed the effects of AGEs. Western blot analysis data demonstrated that AGEs increased the protein expression levels of PI3K and AKT, and decreased the expression of E-cadherin. The results suggested that AGEs exert a positive effect on the proliferation, invasion and EMT in SW480 cells through the PI3K/AKT signaling pathway.
\end{abstract}

\section{Introduction}

Colon cancer is the third most commonly diagnosed cancer and poses a serious threat to public health (1). Worldwide, 608,700 individuals succumb to colon cancer and there are $\sim 1.4$ million incident cases each year $(2,3)$. The pathogenesis

Correspondence to: Dr Huasheng Liang, Institute of Endocrine and Metabolic Diseases, Beihai People's Hospital, 83 Heping Road, Haicheng, Beihai, Guangxi Zhuang Autonomous Region 536000, P.R. China

E-mail: flochaos@163.com

Key words: advanced glycation end products, proliferation, invasion, epithelial-mesenchymal transition, PI3K/AKT of colon cancer is complicated; therefore, despite efforts to understand its pathogenesis to improve treatment options, prognosis and survival within 60 months have remained relatively unchanged. Understanding the pathogenesis of colon cancer may assist in developing effective therapeutics for patients.

Long-term exposure to high concentrations of glucose may lead to glycoxidation of tissue proteins and lipids to produce advanced glycation end products (AGEs) (4-6). Recently, several studies have demonstrated that AGEs and receptor AGEs (RAGEs) serve important roles in proliferation, invasion and epithelial-mesenchymal transition of cells by activating multiple signaling pathways (7-10). AGEs and RAGE may enhance the levels of proliferation and migration of breast cancer through the IKK/NF- $\mathrm{BB}$ signaling pathway in mice (11). Qin et al (12) identified that AGEs promoted cell proliferation and migration through RAGEs and the PI3K/AKT pathway. Conversely, Li et al (13) revealed that AGEs and RAGEs decreased cell proliferation through the PI3K/AKT signaling pathway (13). Therefore, the effects of AGEs and RAGEs on proliferation and migration of cells are controversial.

Epithelial-mesenchymal transition (EMT) of cancer cells results in an increase in migration and invasion of cancer

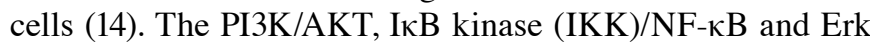
pathways were demonstrated to contribute to EMT (15-17). Therefore, the hypothesis of the present study was that AGEs may affect proliferation, invasion and EMT in human SW480 colon cancer cells through the PI3K/AKT signaling pathway. The aim of the present study was to determine the mechanism underlying the AGEs-mediated induction of proliferation, invasion and EMT in SW480, and potentially highlight novel therapeutic targets for treating patients with colon cancer.

\section{Materials and methods}

Reagents. FBS, RPMI-1640 medium, PBS and penicillin were obtained from Hyclone; GE Healthcare Life Sciences. LY294002, a commonly used broad-spectrum inhibitor of PI3K, was obtained from Selleck Chemicals. AGEs were obtained from Shanghai Yuanmu Biotechnology, Co., Ltd.

Cell culture. SW480 colon cancer cells were purchased from the American Type Culture Collection. Cells were cultured 
in RPMI-1640 medium (cat. no. SH30809.01B) supplemented with $10 \%$ FBS (cat. no. SH30087.01) and $1 \%$ penicillin (cat. no. $\mathrm{SH} 30010$ ) with $5 \% \mathrm{CO}_{2}$ at $37^{\circ} \mathrm{C}$. At $100 \%$ confluence, SW480 cells were passaged using trypsin-EDTA.

MTT assay. Cell proliferation was evaluated using a CellTiter 96 ${ }^{\circledR}$ AQueous One Solution Cell Proliferation assay (MTT assay), purchased from Promega Corporation. SW480 cells were seeded in a 96-well plate at a density of $1 \times 10^{4}$ cells per well and incubated in a $37^{\circ} \mathrm{C}$ incubator for $12 \mathrm{~h}$. Subsequently, cells were washed with PBS twice and treated with AGEs as aforementioned. The proliferation of SW480 cells was detected on days $0,1,2$, and 3. A total of $10 \mu \mathrm{l}$ MTT reagent was added to each well of the 96 -well plate for $4 \mathrm{~h}$. Cell proliferation was measured at a wavelength of $490 \mathrm{~nm}$ at the different time points using a microplate reader (Thermo Fisher Scientific, Inc.). The inhibition rate was calculated as: 1-[optical density (OD) value of experimental group/OD value of control group] x100, and the proliferation ratio was calculated as follows: [(Mean OD value at time point/mean OD at day 0)-1] x100.

Cell cycle progression and apoptosis. Following transfection for $48 \mathrm{~h}$, SW480 cells were washed twice with pre-cooled PBS and fixed with pre-cooled $70 \%$ ethanol overnight at $4^{\circ} \mathrm{C}$. Subsequently, cells were resuspended in $500 \mu \mathrm{l}$ PBS containing propidium iodide (PI; $50 \mu \mathrm{g} / \mathrm{ml}$ ) staining solution with $0.2 \%$ Triton X-100 and RNase A $(100 \mu \mathrm{g} / \mathrm{ml})$, and incubated for $30 \mathrm{~min}$ at $4^{\circ} \mathrm{C}$ in the dark. Cell cycle distribution was measured using a BD FACScalibur ${ }^{\mathrm{TM}}$ flow cytometer (BD Biosciences) and ModFit LT v.4.0 (BD Biosciences). To measure apoptosis, $1.25 \mu \mathrm{l}$ Annexin V-fluorescein isothiocyanate were added to $500 \mu \mathrm{l} 1 \mathrm{X}$ binding buffer, and cells were incubated with this solution in the dark and at room temperature for $15 \mathrm{~min}$. Eventually, $10 \mu \mathrm{l}$ PI was added to the cells that were left in the dark at room temperature for $15 \mathrm{~min}$. Apoptosis was measured using flow cytometry as aforementioned immediately.

Transwell invasion assay. Transwell invasion assays were used to determine cell invasion. BD Matrigel ${ }^{\mathrm{TM}}$ (BD Biosciences), diluted 1:3 in RPMI-1640 medium, was added to cold Transwell chambers (BD Biosciences) and incubated at $37^{\circ} \mathrm{C}$ for $2 \mathrm{~h}$. Following transfection, SW480 cells were resuspended in $100 \mu \mathrm{l}$ serum-free medium and added to the upper chamber of a Transwell insert, and allowed to incubate at $5 \% \mathrm{CO}_{2}$ at $37^{\circ} \mathrm{C}$ for 24 and $48 \mathrm{~h}$. Cells in the upper chamber were fixed in $4 \%$ paraformaldehyde for $15 \mathrm{~min}$. Following fixing, the cells were washed in PBS, stained with crystal violet for $10 \mathrm{~min}$ and counted at magnification, $x 400$ on an inverted optical microscope imaging system.

Wound healing assay. Cell migration was determined using a wound healing assay. SW480 cells were seeded in a 6-well plate at a density of $1 \times 10^{6}$ cells per well and incubated with $5 \%$ $\mathrm{CO}_{2}$ at $37^{\circ} \mathrm{C}$. At $80 \%$ confluence, SW480 cells were scratched to create a cell-free area using a sharp edge. Cells were washed with PBS, serum-free medium was added and the cells were incubated at $37^{\circ} \mathrm{C}$ for 0,24 and $48 \mathrm{~h}$. Cell migration into the scratched area was imaged every $24 \mathrm{~h}$ following scratching using an inverted optical microscope (magnification, x100). The width of the scratched area was measured using Image
Pro-Plus version 6.0 (Media Cybernetics, Inc.). The migration rate was calculated using the following formula: 1-(wound width at indicated time/wound width at day 0) x100.

Western blot analysis. Total protein was extracted from cultured SW480 cells using RIPA buffer (RIPA: $50 \mathrm{mM}$ Tris-HCL PH 7.4; 150 mM NaCL; 1 mM EDTA; 1\% Triton $\mathrm{X}-100 ; 0.5 \%$ sodium deoxycholate; $0.1 \%$ SDS; $100 \mathrm{mM}$ PMSF) containing phosphatase and protease inhibitor cocktail (100X; cat. no. 539131; Calbiochem; Merck KGaA) $4^{\circ} \mathrm{C}$ for $15 \mathrm{~min}$. Protein concentration was measured using Bicinchoninic acid assay (Thermo Fisher Scientific, Inc.). A total of $40 \mu \mathrm{g}$ protein was loaded on a $12 \%$ SDS-PAGE gel and transferred to a PVDF membrane (EMD Millipore). Membranes were blocked with 5\% non-fat milk in TBS-Tween [TBST; $150 \mathrm{mmol} / \mathrm{l} \mathrm{NaCl}, 10 \mathrm{mmol} / \mathrm{l}$ Tris- $\mathrm{HCl}$ (pH 8.0) and $0.1 \%$ Tween-20] for $1 \mathrm{~h}$ at room temperature. Membranes were washed 3 times with TBST and incubated with one of the following primary antibodies: AKT (Abcam; cat. no. ab8805; 1:1,000), PI3K (Abcam; cat. no. ab151549; 1:1,000), epithelial cadherin (E-cadherin; Abcam; cat. no. ab194982; 1:1,000) and GAPDH (Abcam; cat. no. ab8245; 1:1,000) at $4^{\circ} \mathrm{C}$ overnight. Membranes were washed 3 times with TBST, and subsequently incubated for $1 \mathrm{~h}$ at room temperature with either an immunoglobulin $\mathrm{G}$ horseradish peroxidase conjugated-anti-rabbit or anti-rat secondary antibodies (cat. no. BA1058, Wuhan Boster Biological Technology, Ltd.; 1:2,000). Following incubation with the secondary antibody, the membranes were washed with TBST, and signals were visualized using Immobilon Western Chemiluminescent Substrate (EMD Millipore).

Statistical analysis. Comparisons between the control and the experimental groups were performed using a one-way analysis of variance followed by Student-Newman-Keuls post hoc test for pairwise comparison between groups using SPSS v.20.0 (IBM Corp.). Data are presented as the mean \pm standard deviation. $\mathrm{P}<0.05$ was considered to indicate a statistically significant difference.

\section{Results}

Effect of AGEs on proliferation of SW480 cells. SW480 cells were divided into three groups: i) Control; ii) cells treated with AGEs alone; and iii) cells treated with AGEs and LY294002 (Fig. 1). Compared with the control group, the absorbance values of cells treated with AGEs was significantly increased, particularly on days $2(\mathrm{P}<0.001)$ and $3(\mathrm{P}<0.001)$. The absorbance values of cells treated with AGEs and LY294002 was significantly decreased compared with cells treated with AGEs alone on day $1(\mathrm{P}<0.001)$ and $2(\mathrm{P}<0.05)($ Fig. $1 \mathrm{~A})$. The proliferation ratio of cells treated with AGEs alone was also significantly increased on days $1(\mathrm{P}<0.05)$ and $2(\mathrm{P}<0.001)$ and $3(\mathrm{P}<0.001)$ compared with the control group. The proliferation ratio of cells treated with AGEs and LY294002 was also significantly increased on days $2(\mathrm{P}<0.05)$ compared with the control group (Fig. 1B). Conversely, the proliferation ratio of cells treated with AGEs and LY294002 was significantly decreased compared with cells treated with AGEs alone on day 3 (Fig. 1B). As demonstrated in Fig. 1C, the inhibition rate of cells treated with AGEs alone was significantly decreased compared with 


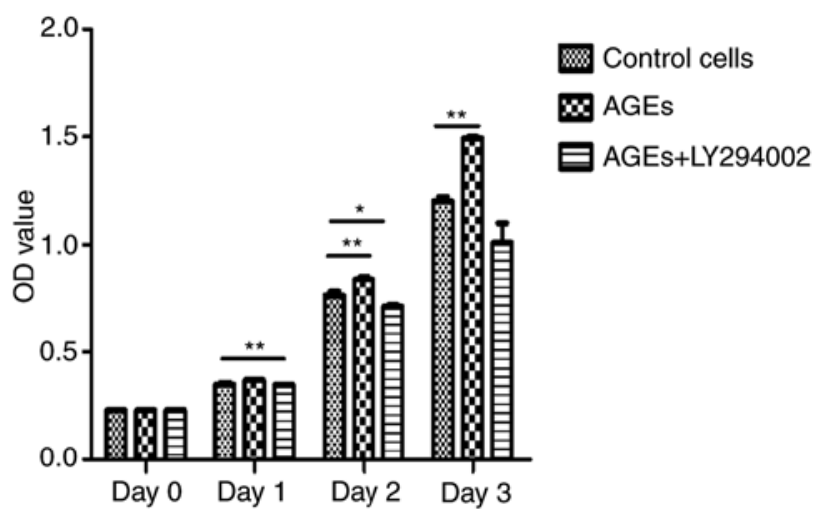

B

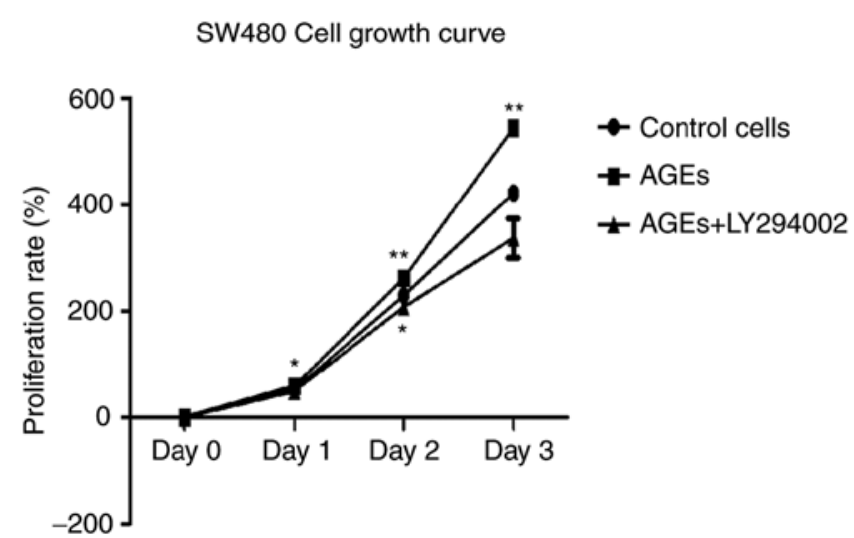

C

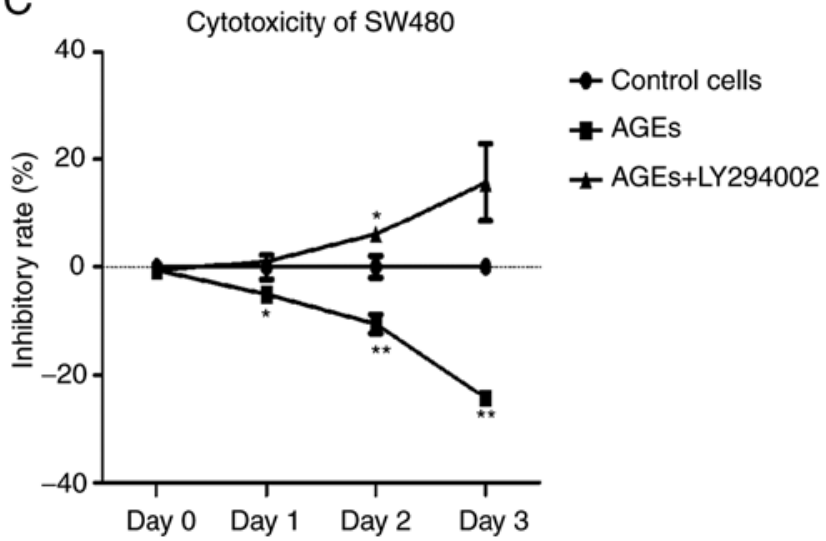

Figure 1. Effect of AGEs on proliferation of SW480 cells. (A) MTT assays were performed to measure cell proliferation on cells treated with AGEs alone or with LY294002 for 0, 1, 2 and 3 days. OD was measured at $490 \mathrm{~nm}$. Data are presented as the mean \pm standard deviation of 3 repeat experiments. "P<0.05 and ${ }^{* *} \mathrm{P}<0.001$ vs. control. (B) Proliferation and (C) inhibition rates of cells treated with AGEs alone or with LY294002 for 0, 1, 2 and 3 days. OD was measured at $490 \mathrm{~nm}$. Data are presented as the mean \pm standard deviation of 3 repeat experiments. ${ }^{*} \mathrm{P}<0.05$ and ${ }^{* *} \mathrm{P}<0.001$ vs. control. AGEs, advanced glycation end products; OD, optical density.

the inhibition rate of cells treated AGEs and LY294002. These results suggest that AGEs may enhance proliferation of SW480 cells through the PI3K signaling pathway.

Effect of AGEs on cell cycle distribution and apoptosis in SW480 cells. Figs. 2 and 3 demonstrate the effects of AGEs on cell cycle distribution and apoptosis in SW480 cells. Compared with the control group, in cells treated with AGEs alone there was a decrease in the percentage of cells in G1-phase and increase in the proportion of cells in S-phase. Treatment with LY294002 abrogated the effects of AGEs on cell cycle distribution (Fig. 2). As indicated in Fig. 3, treatment with AGEs alone decreased the apoptotic rate in cells, and similar to the effects on cell cycle distribution, LY294002 reversed this effect. These data suggest that AGEs decreased the number of cells arrested at G1/S phase and decreased apoptosis through the PI3K signaling pathway.

AGEs increases the migratory and invasive capacity of SW480 cells. The results from the Transwell invasion assay suggested that treatment with AGEs increased the invasive capacity of cells compared with the control group, and LY294002 abrogated the effects of AGEs on invasion (Fig. 4A). Similarly, wound closure was increased in cells treated with AGEs compared with the control cells and cells treated with AGEs and LY294002 ( $\mathrm{P}<0.001)$ on days 1 and 2 (Fig. 4B and C). As demonstrated in Fig. $4 \mathrm{D}$, the migratory rate cells treated with AGEs was significantly increased compared with the other two groups on days 1 and $2(\mathrm{P}<0.001)$. Conversely, the migratory rate of cells treated with AGEs and LY294002 significantly decreased compared with the two groups on days 1 and 2 $(\mathrm{P}<0.001)$. The results of the invasion and wound healing assays suggest that AGEs enhanced the invasive and migratory capacity of cells through the PI3K signaling pathway.

Analysis of the effects of AGEs on EMT. The protein expression levels of PI3K, AKT and E-cadherin were assessed to determine the effects of AGEs on EMT through the PI3K/AKT signaling pathway in SW480 cells. AGEs increased the expression of PI3K and AKT, and decreased the expression of E-cadherin in a concentration dependent manner (Fig. 5). These results suggest that AGEs may induce EMT in SW480 cells through the PI3K/AKT signaling pathway.

\section{Discussion}

The effect of AGEs on cancer development has garnered increasing interest in recent years. In vitro assays in a number 

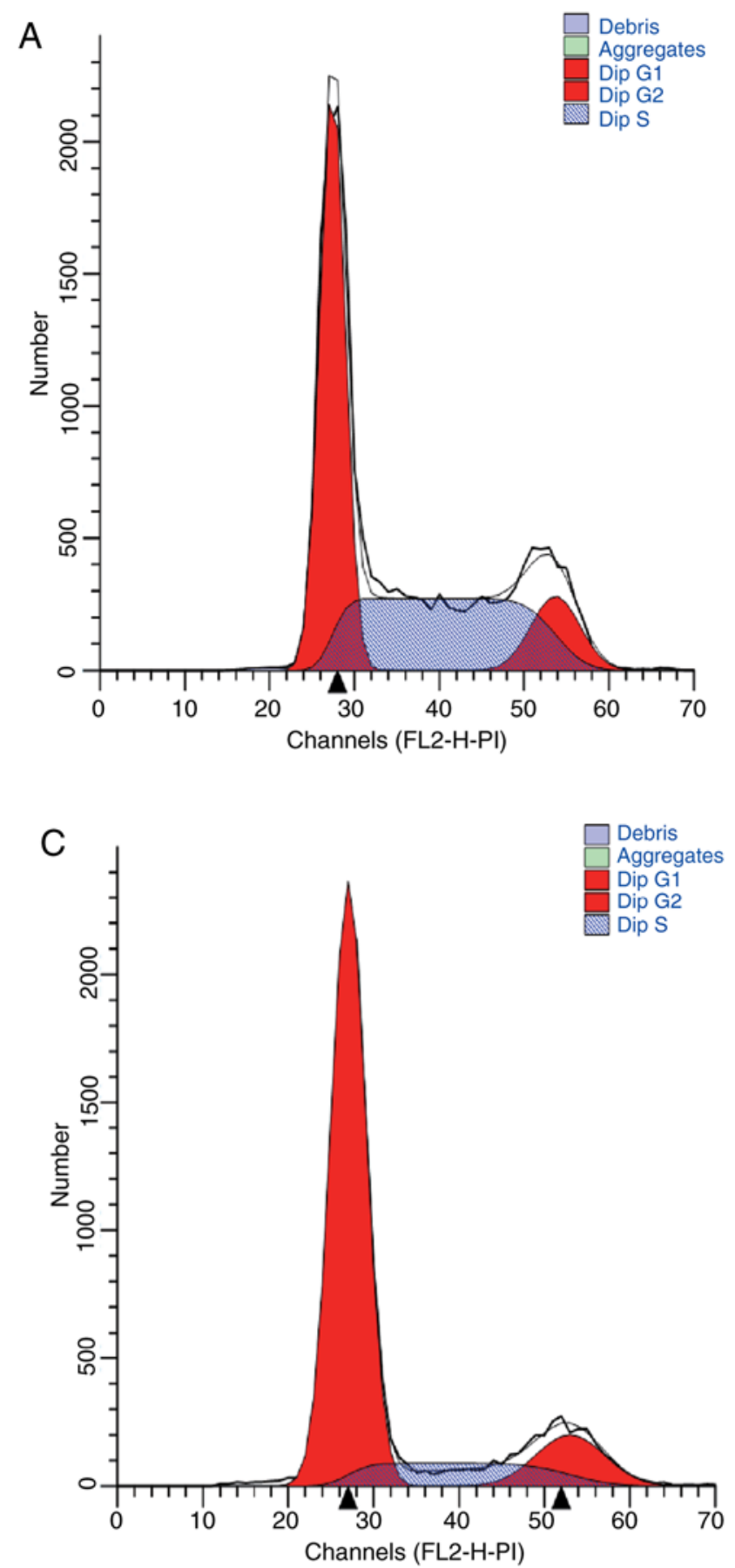
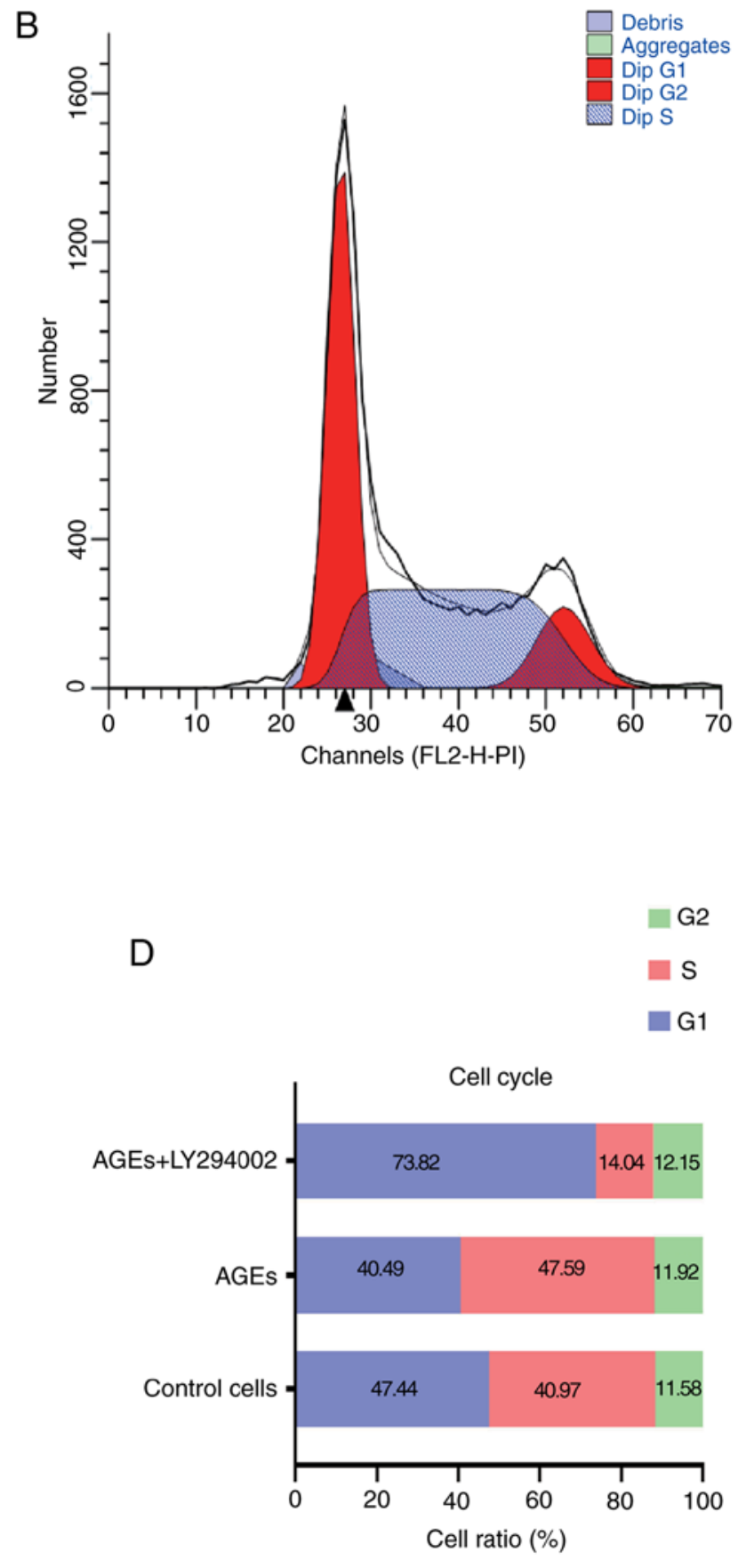

Figure 2. Effect of AGEs on cell cycle distribution of SW480 cells. Cell cycle distribution in SW480 cells was determined using flow cytometry in the (A) control group, (B) cells treated with AGEs alone and (C) cells treated with AGEs combined with LY294002. (D) Proportions of cells in the different phases of the cycle. AGEs, advanced glycation end products.

of studies have indicated that AGEs increase proliferation, invasion and migration in colon $(18,19)$, pancreatic $(20)$, liver $(21)$, breast $(22,23)$ and renal cancer $(24)$. Data from epidemiological and animal studies have also suggested that AGEs increase the risk of cancer development (25-28). In the present study, the results demonstrated that AGEs increased proliferation, invasion and migration, and decreased apoptosis in SW480 cells. PI3K is a central protein involved in PI3K/AKT signaling. PI3K activates lipids on cell membranes through a number of signals, including hormones, growth factors and extracellular matrix components (29). LY294002 is the first synthetic molecule known to inhibit PI3K $\alpha / \beta / \delta$ function (12) and in cells treated with LY294002, Akt phosphorylation was decreased, resulting in inhibition of cell proliferation (30). A previous study demonstrated that LY294002 significantly inhibited growth and induced apoptosis of colon cancer cells in vitro, by decreasing phosphorylation of Akt on Ser473 (31). In addition, LY294002 inhibits proliferation of ovarian cancer cells by inducing marked nuclear pyknosis and decreasing cytoplasmic volume in the tumor cells (32). The results of the present study indicated that the effects of AGEs on proliferation, invasion, migration and apoptosis were 

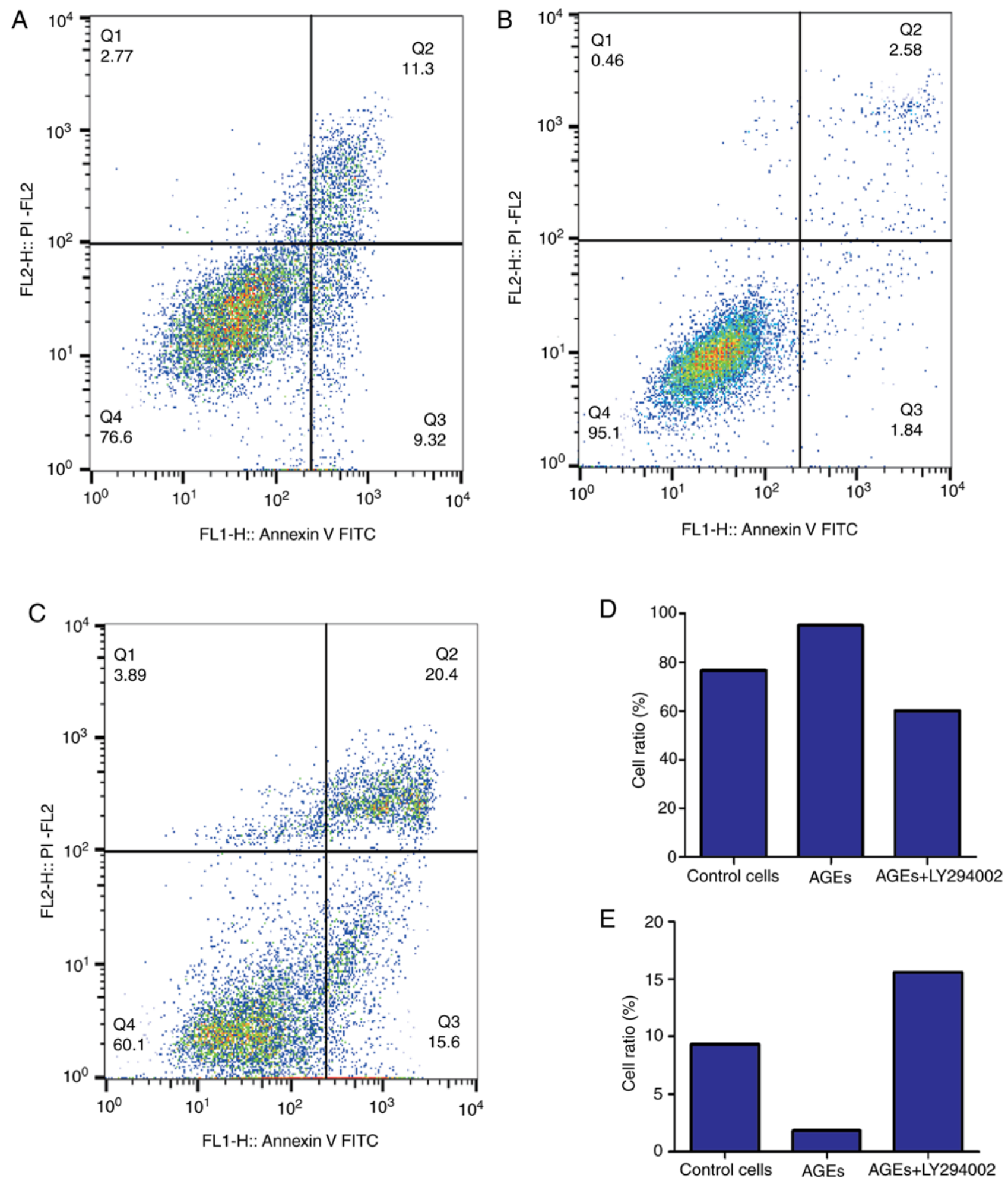

Figure 3. Effect of AGEs on apoptosis of SW480 cells. Apoptosis of SW480 cells was measured using flow cytometry. Apoptotic rate in the (A) control group, (B) cells treated with AGEs alone and (C) cells treated with AGEs combined with LY294002. Proportion of healthy (D) normal cell and (E) apoptotic cells following treatment. AGEs, advanced glycation end products. AGEs, advanced glycation end products; PI, propidium iodide; FITC, fluorescein isothiocyanate.

abrogated by treatment with LY294002 in the SW480 cells. Therefore, PI3K/AKT signaling may underlie the mechanism by which AGEs regulates proliferation, invasion, migration and apoptosis in SW480 cells.

The PI3K/AKT signaling pathway is a significant intracellular signaling pathway involved in regulation of a number of cellular behaviors, including proliferation, metabolism and apoptosis (33-35), and is frequently activated in cancer cells (36). Boudot et al (37) and Granado et al (38) demonstrated that AKT regulated cell migration through enhancing AKT signaling. Consistent with Boudot et al (37) and Granado et al $(37,38)$ the expression of AKT protein was increased in SW480 cells treated with AGEs in the present study. Western blot analysis demonstrated that the expression 
A

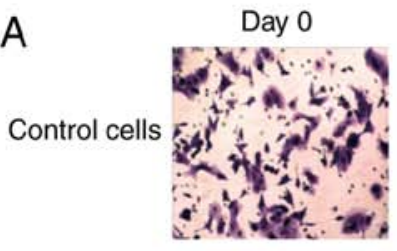

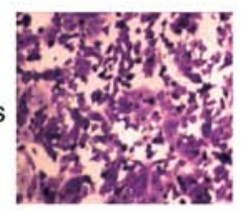

Day 3
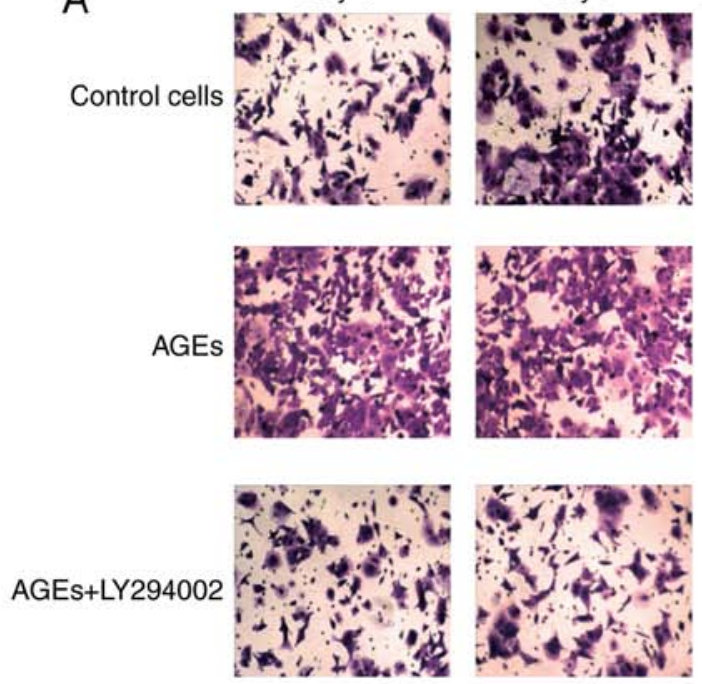

C

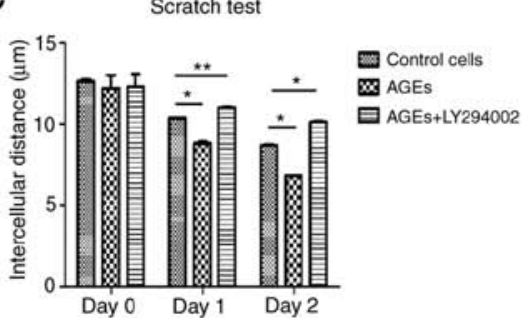

B Day 0
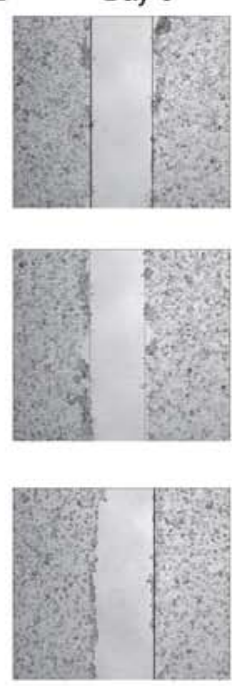

D
Day 1
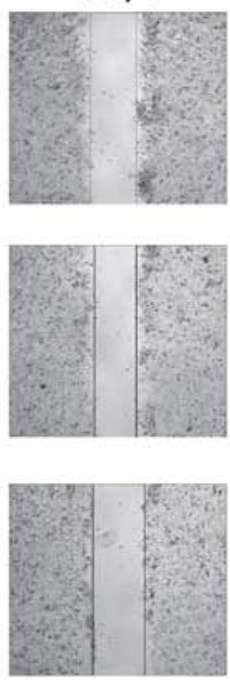

Scratch test

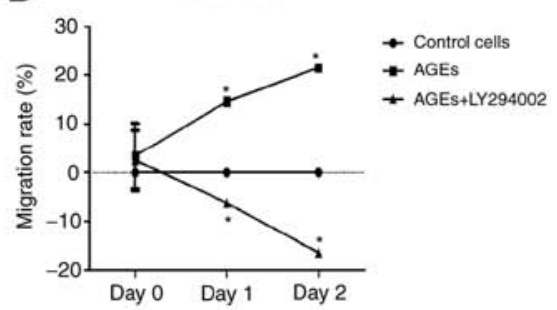

Control cells

AGEs
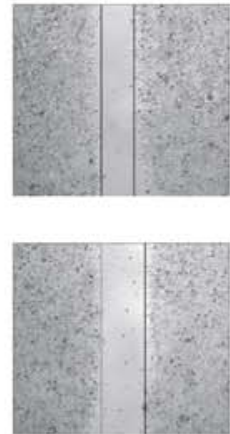

AGEs+LY294002

Figure 4. AGEs induce invasion and migration in SW480 cells. (A) Transwell invasion assays were used to determine the effects of AGEs and LY294002 on the invasive capacity after 0 and 3 days of treatment. (B) The results of cell migration in the control, AGEs and AGEs + LY294002 groups at 0,24 and 48 h. (C) Cell migration was significantly increased in cells treated with AGEs, and the addition of LY294002 significantly reversed the effects of AGEs on migration. ${ }^{*} \mathrm{P}<0.05$ and ${ }^{* *} \mathrm{P}<0.001$ vs. control. (D) Migration rate was quantified for the various treatments. ${ }^{*} \mathrm{P}<0.05$ vs. control. AGEs, advanced glycation end products.
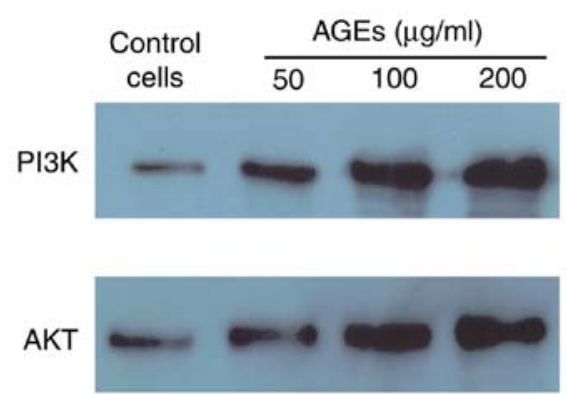

E-cadherin

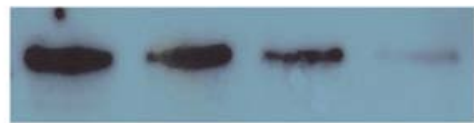

GAPDH

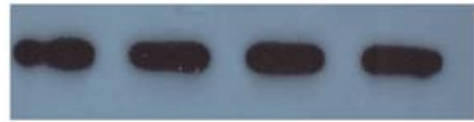

Figure 5. Expression of PI3K, AKT, E-cadherin in AGEs-induced SW480 cells. SW480 cells were treated with different concentrations of AGEs and protein expression levels were determined using western blot analysis. AGEs, advanced glycation end products; E-cadherin, epithelial cadherin.

of PI3K protein was also increased in SW480 cells treated with AGEs. These results suggest that AGEs may increase the protein expression levels of AKT by increasing the expression of PI3K, thereby inhibiting apoptosis and promoting proliferation in SW480 cells. Furthermore, expression of E-cadherin was decreased in SW480 cells following treatment with various concentrations of AGEs.

E-cadherin is a commonly used marker of EMT. EMT is a complex biochemical process underlying increased migration and invasion in cancer cells (39). Prieto-García et al (40) demonstrated that EMT increased migration in epithelial tumor cells. If expression of E-cadherin is decreased, breast cancer cells undergo EMT through activation of the NF-KB signaling pathway (41). In the present study, the western blot analysis data indicated that E-cadherin expression was decreased following treatment with AGEs. Therefore, it is hypothesized that the PI3K/AKT signaling pathway serves an important role in AGEs-mediated activation of EMT through decreasing expression of E-cadherin.

In conclusion, to the best of our knowledge, the present study is the first to demonstrate that AGEs induce proliferation, invasion and EMT in SW480 cells through the PI3K/AKT signaling pathway. AGEs increased the expression of PI3K and AKT, which resulted in increased levels of proliferation, invasion and EMT, thus identifying an association between AGEs and colon cancer, and highlighting potentially novel therapeutic targets for treatment of colon cancer.

\section{Acknowledgements}

Not applicable. 


\section{Funding}

The present study was funded by the Key Projects of Guangxi Natural Science Foundation (grant no. 2013GXNSFDA019019); the '139' plan for Training High Level Cadre Talents in Guangxi Medicine; Guangxi Special Fund Project for Cultivating Academic and Technical Leaders in the New Century; The Second Level in Guangxi New Century Ten, Hundred and Thousand Talents Project.

\section{Availability of data and materials}

The datasets used and/or analyzed during the present study are available from the author on reasonable request.

\section{Authors' contributions}

HL was involved in the conception and design of this study, drafting the article and revising the manuscript.

\section{Ethics approval and consent to participate}

Not applicable.

\section{Patient consent for publication}

Not applicable.

\section{Competing interests}

The authors declare that they have no competing interests.

\section{References}

1. Cao H, Xu E, Liu H, Wan L and Lai M: Epithelial-mesenchymal transition in colorectal cancer metastasis: A system review. Pathol Res Pract 211: 557-569, 2015.

2. Kang KA, Piao MJ, Ryu YS, Hyun YJ, Park JE, Shilnikova K, Zhen AX, Kang HK, Koh YS, Jeong YJ and Hyun JW: Luteolin induces apoptotic cell death via antioxidant activity in human colon cancer cells. Int J Oncol 51: 1169-1178, 2017.

3. Ferlay J, Shin HR, Bray F, Forman D, Mathers C and Parkin DM: Estimates of worldwide burden of cancer in 2008: GLOBOCAN 2008. Int J Cancer 127: 2893-2917, 2010.

4. Brownlee M: Advanced protein glycosylation in diabetes and aging. Annu Rev Med 46: 223-234, 1995.

5. Hori O, Yan SD, Ogawa S, Kuwabara K, Matsumoto M, Stern D and Schmidt AM: The receptor for advanced glycation end-products has a central role in mediating the effects of advanced glycation end-products on the development of vascular disease in diabetes mellitus. Nephrol Dial Transplant 11 (Suppl 5): S13-S16, 1996.

6. Schmidt AM, Yan SD, Wautier JL and Stern D: Activation of receptor for advanced glycation end products: A mechanism for chronic vascular dysfunction in diabetic vasculopathy and atherosclerosis. Circ Res 84: 489-497, 1999.

7. Bao JM, He MY, Liu YW, Lu YJ, Hong YQ, Luo HH, Ren ZL, Zhao SC and Jiang Y: AGE/RAGE/Akt pathway contributes to prostate cancer cell proliferation by promoting $\mathrm{Rb}$ phosphorylation and degradation. Am J Cancer Res 5: 1741-1750, 2015.

8. Lee KJ, Yoo JW, Kim YK, Choi JH, Ha TY and Gil M: Advanced glycation end products promote triple negative breast cancer cells via ERK and NF- $\kappa$ B pathway. Biochem Biophys Res Commun 495: 2195-2201, 2018.

9. Neviere R, Yu Y, Wang L, Tessier F and Boulanger E: Implication of advanced glycation end products (Ages) and their receptor (Rage) on myocardial contractile and mitochondrial functions. Glycoconj J 33: 607-617, 2016.
10. Sun L, Huang T, Xu W, Sun J, Lv Y and Wang Y: Advanced glycation end products promote VEGF expression and thus choroidal neovascularization via Cyr61-PI3K/AKT signaling pathway. Sci Rep 7: 14925, 2017.

11. Nasser MW, Wani NA, Ahirwar DK, Powell CA, Ravi J, Elbaz M, Zhao H, Padilla L, Zhang X, Shilo K, et al: RAGE mediates S100A7-induced breast cancer growth and metastasis by modulating the tumor microenvironment. Cancer Res 75: 974-985, 2015.

12. Qin Q, Niu J, Wang Z, Xu W, Qiao Z and Gu Y: Heparanase induced by advanced glycation end products (AGEs) promotes macrophage migration involving RAGE and PI3K/AKT pathway. Cardiovasc Diabetol 12: 37, 2013.

13. Li G, Xu J and Li Z: Receptor for advanced glycation end products inhibits proliferation in osteoblast through suppression of Wnt, PI3K and ERK signaling. Biochem Biophys Res Commun 423: 684-689, 2012.

14. Thiery JP: Epithelial-mesenchymal transitions in tumour progression. Nat Rev Cancer 2: 442-454, 2002.

15. Karin M, Yamamoto Y and Wang QM: The IKK NF-kB system: A treasure trove for drug development. Nat Rev Drug Discov 3: 17-26, 2004.

16. Downward J: Targeting RAS signalling pathways in cancer therapy. Nat Rev Cancer 3: 11-22, 2003.

17. Huber MA, Kraut N and Beug H: Molecular requirements for epithelial-mesenchymal transition during tumor progression. Curr Opin Cell Biol 17: 548-558, 2005.

18. Shimomoto T, Luo Y, Ohmori H, Chihara Y, Fujii K, Sasahira T, Denda A and Kuniyasu H: Advanced glycation end products (AGE) induce the receptor for AGE in the colonic mucosa of azoxymethane-injected Fischer 344 rats fed with a high-linoleic acid and high-glucose diet. J Gastroenterol 47: 1073-1083, 2012.

19. Chen H, Wu L, Li Y, Meng J, Lin N, Yang D, Zhu Y, Li X, Li M, $\mathrm{Xu} \mathrm{Y}$, et al: Advanced glycation end products increase carbohydrate responsive element binding protein expression and promote cancer cell proliferation. Mol Cell Endocrinol 395: 69-78, 2015.

20. Grote VA, Nieters A, Kaaks R, Tjønneland A, Roswall N, Overvad K, Nielsen MR, Clavel-Chapelon F, Boutron-Ruault MC, Racine A, et al: The associations of advanced glycation end products and its soluble receptor with pancreatic cancer risk: A case-control study within the prospective EPIC cohort. Cancer Epidemiol Biomarkers Prev 21: 619-628, 2012.

21. Takino J, Yamagishi S and Takeuchi M: Glycer-AGEs-RAGE signaling enhances the angiogenic potential of hepatocellular carcinoma by upregulating VEGF expression. World J Gastroenterol 18: 1781-1788, 2012.

22. Ishibashi Y, Matsui T, Takeuchi M and Yamagishi S: Metformin inhibits advanced glycation end products (AGEs)-induced growth and VEGF expression in MCF-7 breast cancer cells by suppressing AGEs receptor expression via AMP-activated protein kinase. Horm Metab Res 45: 387-390, 2013.

23. Chen H, Li Y, Zhu Y, Wu L, Meng J, Lin N, Yang D, Li M, Ding W, Tong X and Su Q: Advanced glycation end products promote ChREBP expression and cell proliferation in liver cancer cells by increasing reactive oxygen species. Medicine (Baltimore) 96: e7456, 2017.

24. Liu X, Liu K, Wang Z, Liu C, Han Z, Tao J, Lu P, Wang J, Wu B, Huang Z, et al: Advanced glycation end products accelerate arteriosclerosis after renal transplantation through the AGE/RAGE/ILK pathway. Exp Mol Pathol 99: 312-319, 2015.

25. Foster D, Spruill L, Walter KR, Nogueira LM, Fedarovich H, Turner RY, Ahmed M, Salley JD, Ford ME, Findlay VJ and Turner DP: AGE metabolites: A biomarker linked to cancer disparity? Cancer Epidemiol Biomarkers Prev 23: 2186-2191, 2014.

26. Vlassara $\mathrm{H}$ and Uribarri J: Advanced glycation end products (AGE) and diabetes: Cause, effect, or both? Curr Diab Rep 14: 453, 2014.

27. Duan Z, Chen G, Chen L, Stolzenberg-Solomon R, Weinstein SJ, Mannisto S, White DL, Albanes D and Jiao L: Determinants of concentrations of $\mathrm{N}(\varepsilon)$-carboxymethyl-lysine and soluble receptor for advanced glycation end products and their associations with risk of pancreatic cancer. Int J Mol Epidemiol Genet 5: 152-163, 2014

28. Yang S, Pinney SM, Mallick P, Ho SM, Bracken B and Wu T: Impact of oxidative stress biomarkers and carboxymethyllysine (an advanced glycation end product) on prostate cancer: A prospective study. Clin Genitourin Cancer 13: e347-e351, 2015.

29. Nicholson KM and Anderson NG: The protein kinase B/Akt signalling pathway in human malignancy. Cell Signal 14: 381-395, 2002 . 
30. Xin $\mathrm{M}$ and Deng $\mathrm{X}$ : Nicotine inactivation of the proapoptotic function of Bax through phosphorylation. J Biol Chem 280: 10781-10789, 2005.

31. Semba $S$, Itoh $N$, Ito $M$, Harada $M$ and Yamakawa $M$ : The in vitro and in vivo effects of 2-(4-morpholinyl)-8-phenyl-chromone (LY294002), a specific inhibitor of phosphatidylinositol 3'-kinase, in human colon cancer cells. Clin Cancer Res 8: 1957-1963, 2002.

32. Hu L, Zaloudek C, Mills GB, Gray J and Jaffe RB: In vivo and in vitro ovarian carcinoma growth inhibition by a phosphatidylinositol 3-kinase inhibitor (LY294002). Clin Cancer Res 6: 880-886, 2000.

33. Song G, Ouyang G and Bao S: The activation of Akt/PKB signaling pathway and cell survival. J Cell Mol Med 9: 59-71, 2005.

34. Zheng J, Koh X, Hua F, Li G, Larrick JW and Bian JS: Cardioprotection induced by $\mathrm{Na}+\mathrm{K}+-\mathrm{ATPase}$ activation involves extracellular signal-regulated kinase $1 / 2$ and phosphoinositide 3-kinase/Akt pathway. Cardiovasc Res 89: 51-59, 2011.

35. Liu Q, Turner KM, Alfred Yung WK, Chen K and Zhang W: Role of AKT signaling in DNA repair and clinical response to cancer therapy. Neuro Oncol 16: 1313-1323, 2014.

36. Blume-Jensen $P$ and Hunter T: Oncogenic kinase signalling. Nature 411: 355-365, 2001.

37. Boudot C, Saidak Z, Boulanouar AK, Petit L, Gouilleux F, Massy Z, Brazier M, Mentaverri R and Kamel S: Implication of the calcium sensing receptor and the Phosphoinositide 3-kinase/Akt pathway in the extracellular calcium-mediated migration of RAW 264.7 osteoclast precursor cells. Bone 46 : 1416-1423, 2010.
38. Granado MH, Gangoiti P, Ouro A, Arana L, González M, Trueba M and Gómez-Muñoz A: Ceramide 1-phosphate (C1P) promotes cell migration: Involvement of a specific $\mathrm{C} 1 \mathrm{P}$ receptor. Cell Signal 21: 405-412, 2009.

39. Wallesch M, Pachow D, Blücher C, Firsching R, Warnke JP, Braunsdorf WEK, Kirches E and Mawrin C: Altered expression of E-Cadherin-related transcription factors indicates partial epithelial-mesenchymal transition in aggressive meningiomas. J Neurol Sci 380: 112-121, 2017.

40. Prieto-García E, Díaz-García CV, García-Ruiz I and Agulló-Ortuño MT: Epithelial-to-mesenchymal transition in tumor progression. Med Oncol 34: 122, 2017.

41. Huber MA, Azoitei N, Baumann B, Grünert S, Sommer A, Pehamberger H, Kraut N, Beug H and Wirth T: NF-KB is essential for epithelial-mesenchymal transition and metastasis in a model of breast cancer progression. J Clin Invest 114: 569-581, 2004.

(i) $\ominus$ This work is licensed under a Creative Commons Attribution-NonCommercial-NoDerivatives 4.0 International (CC BY-NC-ND 4.0) License. 